\title{
Upaya Meningkatkan Partisipasi Siswa dalam Pembelajaran Sosiologi Melalui Model Prediction Guide dengan Media Gambar Kelas X IPS 3 SMAN12 Padang
}

\author{
Resa Betari ${ }^{1}$, Junaidi Junaidi ${ }^{2}$ \\ ${ }^{1,2}$ Universtitas Negeri Padang \\ Email: resabetari3097@gmail.com, junaidiunp@fis.unp.ac.id
}

\begin{abstract}
Abstrak
Penelitian ini dilatarbelakangi rendahnya partisipasi siswa dalam pembelajaran sosiologi. Rendahnya partisipasi siswa disebabkan kurang tepatnya strategi pembelajaran digunakan guru. Untuk memperbaiki rendahnya partisipasi siswa guru menggunakan model pembelajaran Prediction Guide dengan media gambar. Penelitian ini bertujuan untuk mengetahui peningkatan partisipasi siswa melalui model Prediction Guide dengan media gambar dalam pembelajaran sosiologi. Penelitian ini merupakan penelitian tindakan kelas yang dilakukan dengan 2 siklus. Subjek penelitian adalah siswa kelas X IPS3 SMAN12 Padang berjumlah 36orang. Penelitian dilakukan secara daring melalui aplikasi Zoom Metting dan Whatsapp. Hasil penelitian diolah menggunakan rumus $\mathrm{P}=(\mathrm{F} / \mathrm{N}) \mathrm{X} 100 \%$. Hasil penelitian menunjukkan adanya peningkatan partisipasi siswa, dari pra tindakan sebesar 35\%, siklus I meningkat $67 \%$. Siklus I ke siklus II meningkat sebesar $78 \%$.
\end{abstract}

Kata kunci: Media Gambar, Pembelajaran Sosiologi, Prediction Guide, Partisipasi Siswa)

This research is motivated by the low participation of students in learning sociology. The low student participation is due to the lack of precise learning strategies used by teachers. To improve the low participation of student teachers using the Prediction Guide learning model with media images. This study aims to determine the increase in student participation through the Prediction Guide model with media images in learning sociology. This research is a classroom action research conducted with 2 cycles. The research subjects were 36 students of Social Sciences class X SMAN 12 Padang. The study was conducted online through the Zoom Metting and Whatsapp applications. The results of the study were processed using the formula $P=(F / N) X 100 \%$. The results showed an increase in student participation, from pre-action by 35\%, the first cycle increased by $67 \%$. Cycle I to cycle II increased by $78 \%$.

Keywords: Image Media, Learning Sociology, Prediction Guide, Student Participation)

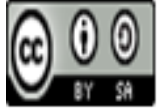

Received: July 29, 2020 Revised: August 17, 2020 Accepted: August 18, 2020 


\section{Pendahuluan}

Pembelajaran merupakan suatu sistem, yang terdiri dari berbagai komponen yang saling berhubungan satu dengan yang lain. Komponen tersebut, meliputi: tujuan, materi, metode, dan evaluasi (Rusman, 2017). Proses pembelajaran adalah upaya yang dilakukan untuk membuat siswa belajar, dalam belajar siswa tidak hanya berinteraksi dengan guru tetapi juga berinteraksi dengan keseluruhan sumber belajar yang digunakan untuk mencapai tujuan pembelajaran (Sunhaji, 2014). Salah satu upaya yang harus dilakukan untuk mengajar siswa untuk belajar dengan cara belajar yang lebih efektif dan efisien. Oleh karena itu, guru memiliki peranan yang penting dalam memilih strategi yang terpat untuk menciptakan partisipasi siswa dalam belajar (Putri \& Junaidi, 2020).

Pembelajaran sosiologi dimaksudkan mengembangkan kemampuan untuk memahami fenomena kehidupan sehari-hari. Materi pembelajaran mencakup konsep dasar dalam mengkaji berbagai fenomena dan permasalahan yang ada di masyarakat. (Pariera, 2015). Tujuan belajar sosiologi adalah untuk merangsang keterlibatan siswa yang berkaitan dengan pengelolaan pengetahuan, nilai kemanusiaan dan keterlibatan sosial. Peserta didik dapat memiliki kemampuan memahami konsep-konsep sosiologi, memahami berbagai peran sosial dalam masyarakat, dan menumbuhkan sikap kepedulian sosial dalam hidup bermasyarakat (Sylvia et al., 2019). Secara etimologis, kata partisipasi berasal dari bahasa belanda "Participatie" atau dalam bahasa inggris "Participation" yang berarti ikut serta dalam suatu kegiatan atau aktivitas (Syafitri, 2016). Menurut Dr. Made Pidarta partisipasi adalah keterlibatan seseorang dalam suatu kegiatan yang dapat berupa keterlibatan mental dan emosi serta fisik dalam menggunakan kemampuan yang dimilikinya. Keterlibatan dalam melakukan semua kegiatan yang dilaksanakan serta bertanggung jawab dalam keterlibatan (Dwiningrum, 2011). Menurut (Sudjana, 2005) partisipasi belajar adalah keikutsertaan seseorang untuk melakukan sesuatu yang seharusnya dilakukan. Keterlibatan siswa ditunjukkan dengan partisipasi siswa seperti, mendengarkan, berdiskusi, menulis laporan, dan sebagainya. (Fatmawati, 2019). Partisipasi belajar sangat diperlukan dalam proses pembelajaran, karena partisipasi belajar menunjukkan apakah proses pembelajaran efektif atau tidak (Jefri \& Junaidi, 2019). Berdasarkan pengamatan yang peneliti lakukan pada siswa kelas X IPS 3 SMAN 12 Padang, adanya masalah yang ditemukan pada saat proses pembelajaran bahwa siswa yang berpartisipasi di dalam kelas terlihat masih sedikit. Hal ini dilihat pada tabel berikut.

Tabel 1. Tingkat Partisipasi Belajar Siswa Kelas X IPS 3 SMAN 12 Padang

\begin{tabular}{|c|c|c|c|c|c|c|}
\hline $\begin{array}{c}\text { Indikator Yang } \\
\text { Diamati }\end{array}$ & $\begin{array}{c}\text { Banyak } \\
\text { Siswa }\end{array}$ & 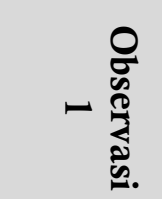 & 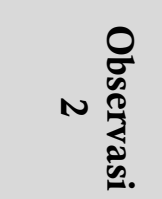 & 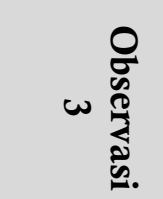 & 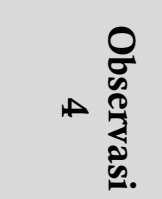 & Rata-rata \\
\hline Bertanya & 36 & $10(28 \%)$ & $10(28 \%)$ & $9(25 \%)$ & $8(22 \%)$ & $26 \%$ \\
\hline $\begin{array}{l}\text { Menjawab } \\
\text { Pertanyaan }\end{array}$ & 36 & $11(31 \%)$ & $8(22 \%)$ & $9(25 \%)$ & $10(28 \%)$ & $27 \%$ \\
\hline $\begin{array}{l}\text { Menyampaikan } \\
\text { Pendapat }\end{array}$ & 36 & $8(22 \%)$ & $7(19 \%)$ & $7(19 \%)$ & $6(17 \%)$ & $19 \%$ \\
\hline Mengerjakan Tugas & 36 & $20(56 \%)$ & $18(50 \%)$ & $17(47 \%)$ & $16(44 \%)$ & $49 \%$ \\
\hline $\begin{array}{l}\text { Mengikuti Pelajaran } \\
\text { Dengan Baik }\end{array}$ & 36 & $22(61 \%)$ & $20(56 \%)$ & $18(50 \%)$ & $15(42 \%)$ & $52 \%$ \\
\hline Rata-rata & & $40 \%$ & $35 \%$ & $33 \%$ & $31 \%$ & $35 \%$ \\
\hline
\end{tabular}

Sumber: Diolah dari data observasi Tahun 2019

Jurnal Sikola: Jurnal Kajian Pendidikan dan Pembelajaran Vol. 2, No. 1, Th. 2020 
Berdasarkan tabel terlihat tingkat partisipasi siswa masih rendah. Tingkat partisipasi belajar siswa rata-rata $35 \%$. Bahkan dari empat kali observasi yang dilakukan terdapat penurunan partisipasi. Hal ini berarti partisipasi belajar siswa rendah. Untuk meningkatkan partisipasi siswa dalam pembelajaran sangat penting untuk menciptakan pembelajaran yang aktif, kreatif, dan menyenangkan (Nurhayati, 2016) . Dengan begitu tujuan pembelajaran yang telah direncanakan bisa tercapai. Oleh karena itu partisipasi siswa yang rendah perlu di tingkatkan.

Model pembelajaran merupakan strategi yang dilakukan guru untuk mengembangkan proses pembelajaran yang meliputi segala aspek dalam pembelajaran serta segala fasilitas yang terkait yang digunakan secara langsung maupu tidak langsung dalam proses pembelajaran (Sundari, 2015). Adapun Soekamto, dkk. (dalam Nurulwati, 2000: 10) menyatakan tujuan model pembelajaran, yaitu: "Kerangka konseptual yang menggambarkan prosedur yang sistematis untuk mengatur pengalaman belajar untuk mencapai tujuan pembelajaran dan memandu perencanaan kegiatan belajar mengajar (Al-Tabany, 2014). Penggunaan model pembelajaran bisa menjadi alternatif menghilangkan rasa jenuh siswa selama proses pembelajaran dan juga dapat meningkatkan antusiasme siswa dalam memperhatikan materi pembelajaran (Fajri et al., 2016). Salah satu model pembelajaran yang penulis anggap tepat untuk meningkatkan partisipasi siswa yaitu model pembelajaran Prediction Guide.

Model pembelajaran Prediction Guide adalah strategi pembelajaran yang dikembangkan oleh Gagne (Mashari, 2017). Model pembelajaran Prediction Guide dikembangkan untuk menarik perhatian siswa selama mengikuti pembelajaran. Model ini digunakan untuk melibatkan peserta didik secara aktif dari awal sampai akhir. Selama penyampaian materi peserta didik dituntut untuk mencocokkan prediksi mereka dengan materi yang disampaikan (Istarani, 2011). Dalam proses pembelajaran dengan menggunakan model Prediction Guide siswa dituntut lebih aktif dalam proses pembelajaran (Mardianto, 2014). Media memiliki peran yang penting di dalam proses kegiatan pembelajaran. Peranan media dalam proses pembelajaran dapat mempengaruhi proses belajar mengajar. (Miftah, 2013). Kehadiran media mempunyai arti yang penting, karena dalam kegiatan pembelajaran ketidakjelasan bahan ajar yang disampaikan dapat terbantu dengan adanya media. Media gambar merupakan suatu objek berupa gambar, kata, simbol dari sebuah peristiwa atau kejadian. Keuntungan menggunakan media diharapkan bisa menarik perhatian siswa dan membuat siswa lebih mengerti dengan materi pembelajaran (Sohibun \& Ade, 2017). Dengan adanya media gambar dapat menyampaikan pemahaman dan informasi dengan cara yang lebih konkret dan nyata dibandingkan dengan kata-kata yang diucapkan (Hilmi, 2016).

\section{Metode Penelitian}

Jenis penelitian ini adalah penelitian tindakan kelas. Penelitian ini dilakukan guru untuk meningkatkan partisipasi siswa dalam pembelajaran sosiologi melalui model Prediction Guide dengan media gambar. Penelitian tindakan kelas terdiri dari 2 siklus. Masing-masing siklus terdiri dari dua kali pertemuan. Terdapat empat jenis kegiatan dalam setiap siklus yaitu perencanaan, tindakan, pengamatan, dan refleksi. Subjek penelitian ini adalah siswa kelas X IPS 3 SMAN 12 Padang yang berjumlah 36 orang. Penelitian ini dilakukan secara daring (Online) melalui aplikasi Zoom Metting dan Whatsapp Instrumen penelitian yang digunakan yaitu lembar observasi dan catatan lapangan. Target partisipasi yang ingin dicapai pada penelitian ini adalah 61 keatas. Berdasarkan kategori interval tersebut maka indikator keberhasilan partisipasi belajar siswa dalam kategori baik. Hasil penelitian partisipasi siswa diolah menggunakan rumus $(\mathrm{P}=\mathrm{F} / \mathrm{N}) \mathrm{X} 100 \%$. 


\section{Hasil dan Pembahasan}

Penelitian tindakan kelas ini terdiri dari 2 siklus yang dimulai dari tahap pra tindakan. Setiap siklus terdiri dari 2 kali pertemuan. Ada 4 jenis kegiatan yang dilakukan dari setiap siklus yaitu perencanaan, tindakan, pengamatan, dan refleksi.

Pada tahap pra tindakan, ditemukan masalah saat proses pembelajaran di dalam kelas terlihat bahwa siswa berpartisipasi masih sedikit. Berikut hasil dari pengamatan yang peneliti lakukan pada saat tahap pra tindakan, pada tabel dibawah:

Tabel 2. Tingkat Partisipasi Belajar Sosiologi Siswa Kelas X IPS 3 Tahap Pra Tindakan

\begin{tabular}{|c|c|c|c|c|c|c|}
\hline $\begin{array}{c}\text { Indikator } \\
\text { Yang Diamati }\end{array}$ & $\begin{array}{l}\text { Banyak } \\
\text { Siswa }\end{array}$ & 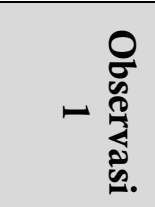 & N $\frac{\substack{0 \\
0}}{4}$ & 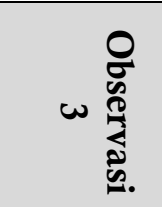 & 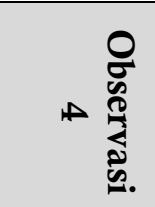 & Rata-rata \\
\hline Bertanya & 36 & $10(28 \%)$ & $10(28 \%)$ & $9(25 \%)$ & $8(22 \%)$ & $26 \%$ \\
\hline $\begin{array}{l}\text { Menjawab } \\
\text { Pertanyaan }\end{array}$ & 36 & $11(31 \%)$ & $8(22 \%)$ & $9(25 \%)$ & $10(28 \%)$ & $27 \%$ \\
\hline $\begin{array}{l}\text { Menyampaikan } \\
\text { Pendapat }\end{array}$ & 36 & $8(22 \%)$ & $7(19 \%)$ & $7(19 \%)$ & $6(17 \%)$ & $19 \%$ \\
\hline $\begin{array}{l}\text { Mengerjakan } \\
\text { Tugas }\end{array}$ & 36 & $20(56 \%)$ & $18(50 \%)$ & $17(47 \%)$ & $16(44 \%)$ & $49 \%$ \\
\hline $\begin{array}{l}\text { Mengikuti } \\
\text { Pelajaran } \\
\text { Dengan Baik }\end{array}$ & 36 & $22(61 \%)$ & $20(56 \%)$ & $18(50 \%)$ & $15(42 \%)$ & $52 \%$ \\
\hline Rata-rata & & $40 \%$ & $35 \%$ & $33 \%$ & $31 \%$ & $35 \%$ \\
\hline
\end{tabular}

Sumber: Diolah dari data obervasi Tahun 2019

Berdasarkan tabel di atas dilihat bahwa partisipasi siswa kelas X IPS 3 SMAN 12 Padang pada pembelajaran sosiologi berada pada kategori rendah yaitu sebesar 35\%. Untuk mengatasi partisipasi siswa yang rendah di atas guru menerapkan model pembelajaran Prediction Guide dengan media gambar untuk meningkatkan partisipasi siswa.

Pada siklus I terjadi peningkatan partisipasi belajar siswa di bandingkan dengan tahap pra tindakan, peningkatan nya dapat dilihat dari data pada tabel berikut:

Tabel 3. Peningkatan Partisipasi Belajar Kelas X IPS 3 Tahap Pra Tindakan dan Siklus I

\begin{tabular}{lccc}
\hline \multicolumn{1}{c}{ Indikator Partisipasi } & $\begin{array}{c}\text { Persentase } \\
\text { Pra Tindakan }\end{array}$ & $\begin{array}{c}\text { Persentase } \\
\text { Siklus I }\end{array}$ & Peningkatan \\
\hline Bertanya & $26 \%$ & $60 \%$ & $34 \%$ \\
\hline Menjawab Pertanyaan & $27 \%$ & $60 \%$ & $33 \%$ \\
\hline Menyampaikan Pendapat & $19 \%$ & $54 \%$ & $35 \%$ \\
\hline Mengerjakan Tugas & $49 \%$ & $81 \%$ & $32 \%$ \\
\hline Mengikuti Pelajaran Dengan Baik & $52 \%$ & $82 \%$ & $30 \%$ \\
\hline Rata-rata & $\mathbf{3 5 \%}$ & $\mathbf{6 7 \%}$ & $\mathbf{3 3 \%}$ \\
\hline
\end{tabular}

Sumber: Diolah dari data pengamatan pra tindakan dan siklus I Tahun 2020

Jurnal Sikola: Jurnal Kajian Pendidikan dan Pembelajaran Vol. 2, No. 1, Th. 2020 
Peneliti melihat peningkatan persentase pada Siklus I yaitu seluruh indikator partisipasi belajar siswa, berbeda pada saat melakukan pengamatan pada tahap pra tindakan. Pada siklus I indikator bertanya dari $26 \%$ meningkat menjadi $60 \%$, peningkatannya sebesar $34 \%$. Indikator menjawab pertanyaan dari $27 \%$ meningkat menjadi $60 \%$, peningkatannya sebesar $33 \%$. Indikator menyampaikan pendapat dari $19 \%$ meningkat menjadi $54 \%$, peningkatannya sebesar $35 \%$. Indikator mengerjakan tugas dari $49 \%$ meningkat menjadi $81 \%$, peningkatannya sebesar $32 \%$. Indikator mengikuti pelajaran dengan baik dari $52 \%$ meningkat menjadi $86 \%$, peningkatannya sebesar $30 \%$.

Berdasarkan pembelajaran pada siklus I yang telah dilaksanakan secara daring (Online) melalui aplikasi Zoom metting dan aplikasi Whatsapp, peneliti dan guru mata pelajaran sosiologi melakukan diskusi untuk melihat kekurangan yang ada selama pelaksanaan tindakan.

Berdasarkan data pada siklus I dapat disimpulkan bahwa tiga indikator partisipasi yang tergolong cukup yaitu pada indikator bertanya, menjawab pertanyaan, dan menyampaikan pendapat. Dibandingkan dengan indikator partisipasi mengerjakan tugas dan mengikuti pelajaran dengan baik tergolong pada kategori baik. Oleh karena itu peneliti beranggapan bahwa tiga indikator yang masih tergolong cukup yaitu pada indikator bertanya, menjawab pertanyaan dan menyempaikan pendapat perlu dilakukan perbaikan sehingga tercapainya target capaian semua indikator pada kategori baik.

Peneliti memutuskan untuk melanjutkannya pada siklus II dengan melakukan perubahan untuk mengatasi kekurangan yang terjadi pada siklus I, yaitu: 1) Memberikan nilai tambahan kepada siswa yang mau bertanya, menjawab pertanyaan, dan menyampaikan pendapat. 2) Guru menyuruh masing-masing siswa untuk menyiapkan satu pertanyaan serta jawabannya. 3) bagi siswa yang tidak fokus saat pembelajaran berlangsung maka namanya akan dicatat dan akan dikurangi nilai sosiologi nya. 4) Guru memberikan pujian kepada siswa, contohnya: bagus, benar, bagus sekali jawabannya. 5.) Guru memberikan motivasi kepada siswa agar siswa mau menyampaikan pendapatnya. 6) Memberi nasihat agar siswa tidak mengejek atau menertawan jawaban teman yang menyampaikan pendapatnya.

Secara keseluruhan pada siklus II adanya peningkatan partisipasi belajar siswa dibandingkan pra tindakan dan siklus I, peningkatannya pada tabel berikut:

Tabel 4. Peningkatan Partisipasi Belajar Siswa Kelas X IPS 3 Tahap Pra Tindakan, Siklus I Dan Siklus II

\begin{tabular}{|c|c|c|c|c|c|}
\hline $\begin{array}{l}\text { Indikator } \\
\text { Partisipasi }\end{array}$ & $\begin{array}{c}\text { Pra } \\
\text { Tindakan }\end{array}$ & Siklus I & $\begin{array}{c}\text { Peningkatan } \\
\text { Pra } \\
\text { Tindakan } \\
\text { Dan Siklus I }\end{array}$ & Siklus II & $\begin{array}{c}\text { Peningkatan } \\
\text { Siklus I Dan } \\
\text { Siklus II }\end{array}$ \\
\hline Bertanya & $26 \%$ & $60 \%$ & $34 \%$ & $70 \%$ & $10 \%$ \\
\hline $\begin{array}{l}\text { Menjawab } \\
\text { Pertanyaan }\end{array}$ & $27 \%$ & $60 \%$ & $33 \%$ & $67 \%$ & $7 \%$ \\
\hline $\begin{array}{l}\text { Menyampaikan } \\
\text { Pendapat }\end{array}$ & $19 \%$ & $54 \%$ & $35 \%$ & $70 \% \%$ & $16 \%$ \\
\hline $\begin{array}{l}\text { Mengerjakan } \\
\text { Tugas }\end{array}$ & $49 \%$ & $81 \%$ & $32 \%$ & $91 \%$ & $10 \%$ \\
\hline $\begin{array}{l}\text { Mengikuti } \\
\text { Pelajaran Dengan } \\
\text { Baik }\end{array}$ & $52 \%$ & $82 \%$ & $30 \%$ & $94 \%$ & $12 \%$ \\
\hline Rata-rata & $35 \%$ & $67 \%$ & $33 \%$ & $78 \%$ & $11 \%$ \\
\hline
\end{tabular}

Sumber: Diolah dari pengamatan pra tindakan, siklus I, siklus II Tahun 2020

Jurnal Sikola: Jurnal Kajian Pendidikan dan Pembelajaran Vol. 2, No. 1, Th. 2020 
Peneliti melihat pada siklus II adanya peningkatan pada beberapa partisipasi belajar siswa dibandingkan pada siklus I. Pada siklus II indikator bertanya siswa meningkat dari $60 \%$ menjadi $70 \%$. Indikator menjawab pertanyaan $60 \%$ meningkat menjadi $67 \%$. Indikator menyampaikan pendapat dari 54\% meningkat menjadi 70\%. Indikator mengerjakan tugas dari $81 \%$ meningkat menjadi 91\% dan Indikator mengerjakan tugas dari 82\% meningkat menjadi 94\%.

Peneliti mendapatkan hasil yang baik dalam penggunaan model pembelajaran Prediction Guide dengan media gambar untuk meningkatkan partisipasi belajar siswa dalam pembelajaran sosiologi. hasilnya yaitu dari lima indikator partisipasi siswa seluruhnya sudah termasuk dalam kategori baik yaitu pada rentang $61 \%$ keatas. Kelima indikator tersebut yaitu, indikator partisipasi bertanya $70 \%$, indikator menjawab pertanyaan $67 \%$, indikator menyampaikan pendapat $70 \%$, indikator mengerjakan tugas $91 \%$ dan indikator mengikuti pelajaran dengan baik 94\%. Jika dirata-ratakan maka persentase partisipasi belajar siswa kelas X IPS 3 SMA Negeri 12 Padang adalah sebesar 78\%.

Berdasarkan analisis dari data pengamatan yang telah peneliti lakukan secara daring (Online) melalui aplikasi Zoom metting dan Whatsapp di kelas X IPS 3 SMA Negeri 12 Padang partisipasi belajar siswa pada siklus I dan siklus II mengalami peningkatan. Peningkatan partisipasi belajar siswa kelas X IPS 3 SMA Negeri 12 Padang yaitu pada siklus I 66\% meningkat pada siklus II menjadi 77\%. Pada indikator bertanya siklus I $60 \%$ siklus II meningkat menjadi $70 \%$. Pada indikator menjawab pertanyaan siklus I sebesar $60 \%$ siklus II meningkat menjadi $67 \%$. Pada indikator menyampaikan pendapat siklus I 54\% meningkat pada siklus II menjadi 70\%. Pada indikator mengerjakan tugas siklus I 81\% meningkat pada siklus II menjadi $91 \%$, pada indikator mengikuti pelajaran dengan baik siklus I $82 \%$ meningkat pada siklus II menjadi $94 \%$. Dari seluruh siklus yang telah dilaksanakan ternyata partisipasi belajar siswa kelas X IPS 3 telah mengalami peningkatan sesuai dengan indikator partisipasi belajar siswa yang diamati. Target dalam penelitian ini sudah tercapai yaitu partisipasi belajar siswa kelas X IPS 3 SMA Negeri 12 padang dalam kategori baik. Model pembelajaran Prediction Guide dikembangkan untuk menarik perhatian siswa selama mengikuti pembelajaran. Dapat dilihat pada siklus I dan siklus II dimana siswa aktif bertanya, menjawab pertanyaan, menyampaikan pendapat dan mengerjakan tugas yang diberikan oleh guru.

Menurut pandangan behavioristik belajar adalah perubahan tingkah laku akibat adanya interaksi stimulus dan respons (Rachmawati, 2015). Berdasarkan teori belajar Behavioristik oleh Thorndike mengatakan bahwa teori Behavioristik yang berkaitan dengan belajar adalah proses interaksi antara stimulus yaitu kelompok penyaji dan guru memberi penjelasan dan memberikan gambar terkait materi pembelajaran agar kelompok lain dapat menebak termasuk kedalam materi pembelajaran yang mana gambar tersebut. dan respons, tanggapan siswa terhadap stimulus yang diberikan oleh kelompok penyaji dan guru. Jelasnya menurut Thorndike, perubahan tingkah laku boleh terwujud sesuatu yang konkret (dapat diamati) seperti indikator partisipasi siswa dalam bertanya, menjawab pertanyaan, menyampaikan pendapat dan sebagainya dan non-konkret (tidak bisa diamati). Belajar dengan menggunakan media pembelajaran akan terbentuk proses penguasaan karena adanya interaksi dalam belajar, dengan menggunakan media gambar siswa menjadi lebih mengerti dan paham dengan materi pembelajaran.

Berdasarkan teori behavioristik partisipasi siswa bisa meningkat karena adanya stimulus yang guru berikan yang menimbulkan reaksi dari siswa berupa respons dalam bentuk partisipasi siswa dalam pembelajaran. Guru memberikan stimulus dengan memberi penjelasan dan memberikan pertanyaan kepada siswa untuk mengetahui bahwa siswa sudah mengerti dengan materi pembelajaran. Selanjutnya respons yang diberikan siswa berupa partisipasi dalam pembelajaran sehingga partisipasi siswa dapat meningkat. 


\section{Kesimpulan}

Berdasarkan data yang diperoleh selama melakukan penelitian secara daring (Online) pada aplikasi Zoom metting dan Whatsapp bahwa pembelajaran menggunakan model Prediction Guide dengan media gambar dapat meningkatkan partisipasi siswa dalam pembelajaran sosiologi di kelas X IPS 3 SMAN 12 Padang. Keseluruhan dari indikator partisipasi belajar siswa meningkat dari tahap pra tindakan $35 \%$ ke siklus I menjadi $67 \%$ peningkatannya yaitu sebesar $33 \%$. Kemudian dari siklus I $67 \%$ meningkat menjadi $78 \%$ peningkatannya yaitu sebesar $11 \%$. Meningkatnya partisipasi belajar siswa karena pembelajaran tidak hanya berpusat kepada guru tetapi juga kepada siswa. Pembelajaran menggunakan model prediction guide dengan media gambar melibatkan siswa secara aktif dari awal hingga akhir pembelajaran. dengan adanya media gambar dapat membantu dan memudahkan siswa dalam memahami pembelajaran. Pembelajaran akan lebih menyenangkan dan menarik serta membuat siswa untuk ikut berpartisipasi dalam pembelajaran.

\section{Daftar Pustaka}

Al-Tabany, T. I. B. (2014). Mendesain Model Pembelajaran Inovatif, Progresif, Dan Kontekstual: Konsep, Landasan, dan Implementasinya Pada Kurikulum 2013 (Kurikulum Tematik Integratif/TKI). Jakarta: Prenamedia Group.

Dwiningrum, S. I. A. (2011). Desentralisasi Dan Prtisipasi Masyarakat Dalam Pendidikan.Yogyakarta: Pustaka Belajar.

Fajri, N., Yoesoef, A., \& Nur, M. (2016). Pengaruh Model Pembelajaran Koperatif Tipe Talking Stick Dengan Stretegi Joyful Learning Terhadap Prestasi Belajar Siswa Pada Mata Pelajaran Ips Kelas VII Mtsn Meuraya Banda Aceh. Jurnal Ilmiah Mahasiswa Pendidikan Sejarah, 1(1), 98-109.

Fatmawati, S. (2019). Efektivitas Forum Diskusi Pada E-Learning Berbasis Moodle Untuk Meningkatkan Partisipasi Belajar. Refleksi Edukatika: Jurnal Ilmiah Kependidikan, 9(2), 211216. http://jurnal.umk.ac.id/index.php/RE

Hilmi. (2016). Efektivitas Penggunaan Media Gambar Dalam Pembelajaran Bahasa Arab. Lantanida Journal, 4(2), 15-23.

Istarani, I. (2011). Model Pembelajaran Inovatif. Medan: Media Persada.

Jefri, J., \& Junaidi, J. (2019). Penerapan Model Talking Stick Untuk Meningkatkan Partisipasi Belajar Siswa Pada Pembelajaran Sosiologi Kelas X IPS 1 SMA Negeri 3 Bukittinggi 2019. Jurnal Perspektif, 2(3), 125-131. doi:10.24036/perspektif.v2i3.74.

Mardianto, M. (2014). Perbedaan Hasil Belajar Ekonomi Antara Model Prediction Guide Dengan Model Konvensional Yang Di Laksanakan Di Kelas X SMA N 2 Koto XI Tarusan. Jurnal Of Economic and Economic Education, 2(2), 45-55.

Mashari, M. (2017). Penerapan Strategi Prediction Guide Terhadap Hasil Belajar. Jurnal Pendidikan Fisika, 5(1), 265-274.

Miftah, M. (2013). Fungsi dan Peran Media Pembelajaran Sebagai Upaya Peningkatan Kemampuan Belajar Siswa. Jurnal Kwangsan, 1(2), 95-105.

Nurhayati. (2016). Peningkatan Partisipasi dan Prestasi Belajar Pkn Dengan Model Pakem Siswa Sekolah Dasar Increasing Participation And Learning Achievement Civics Education Through Pakem Model. Jurnal Pendidikan Sekolah Dasar Ahmad Dahlan, 2(1), 43-51.

Pariera, S. (2015). Pentingnya Rancangan Pembelajaran Sosiologi Bagi Dunia Pendidikan di Timor Leste. Jurnal Inovasi Dan Teknologi Pembelajaran, 1(2), 109.

Putri, W. R., \& Junaidi, J. (2020). Upaya Meningkatkan Minat Belajar Siswa Melalui Penerapan Model Teams Games Tournament ( TGT ) dengan Reward and Punisment pada Pembelajaran Sosiologi di SMAN 3 Padang. Jurnal Sikola, 1(4), 265-272. 
Rachmawati, T. D. (2015). Teori Belajar Dan Proses Pembelajaran Yang Mendidik. Yogyakarta: Penerbit Gava Media.

Rusman, R. (2017). Belajar dan Pembelajaran Berorientasi Standar Proses Pendidikan. Jakarta: Kencana.

Sohibun, S., \& Ade, F. Y. (2017). Pengembangan Media Pembelajaran Berbasis Virtual Class Berbantuan Google Drive. Tadris: Jurnal Keguruan dan Ilmu Tarbiyah, 2(2), 121. https://doi.org/10.24042/tadris.v2i2.2177

Sundari, H. (2015). Model-Model Pembelajaran dan Pemefolehan Bahasa Kedua/Asing. Jurnal Pujangga, 1(2), 106-117.

Sunhaji. (2014). Konsep Manajemen Kelas dan Implikasinya dalam Pembelajaran. Kependidikan, 2(2), $1-10$.

Syafitri, I. (2016). Strategi Kooperatif Learning Merupakan Salah Satu Alternatif Meningkatkan Partisipasi Siswa Tunagrahita Ringan Dalam Pembelajaran IPA (Penelitian Tindakan Kelas di Kelas DVI SLB N Gaanting Bukittinggi). Jurnal Ilmiah Pendidikan Khusus, 5(2), 78-89.

Sylvia, I., Anwar, S., \& Khairani, K. (2019). Pengembangan Instrumen Penilaian Autentik Berbasis Pendekatan Authentic Inquiry Learning Pada Mata Pelajaran Sosiologi di Sekolah Menengah Atas. Jurnal Socius: Journal of Sociology Research And Education, 6(2), $103-$ 120. doi:10.24036/scs.v6i2.162 